\title{
Top-down and bottom-up regulation in a high nutrient-high herbivory coastal ecosystem
}

\author{
Paulina Martinetto ${ }^{1,2, *}$, Mirta Teichberg ${ }^{3}$, Ivan Valiela ${ }^{4}$, Diana Montemayor ${ }^{1,2}$, \\ Oscar Iribarne ${ }^{1,2}$ \\ ${ }^{1}$ Lab. de Ecología, Dpto. de Biología (FCEyN), Universidad Nacional de Mar del Plata, CC 573 Correo Central B7600WAG, \\ Mar del Plata, Argentina \\ ${ }^{2}$ Consejo Nacional de Investigaciones Científicas y Técnicas (CONICET), Avda. Rivadavia 1917, Buenos Aires, Argentina \\ ${ }^{3}$ Leibniz-Zentrum für Marine Tropenökologie, Fahrenheitstrasse 6, 28359 Bremen, Germany \\ ${ }^{4}$ The Ecosystems Center, Marine Biological Laboratory, 7 MBL St., Woods Hole, Massachusetts 02543, USA
}

\begin{abstract}
In this study, carried out in San Antonio Bay (Northern Argentinean Patagonia), we aimed to understand the relative importance of bottom-up and top-down controls on macroalgal blooms in a macrotidal system with high nutrient supply and high consumer abundance. Our results show that nutrients, $\mathrm{pH}$, and $\mathrm{O}_{2}$ concentrations were higher during low tide. A field experiment showed that the biomass accumulation rate of Ulva lactuca ranged from 6 to $12 \% \mathrm{~d}^{-1}$ and was reduced by herbivory by $60 \%$. The biomass accumulation rate did not differ in thalli with different initial internal nutrient pools. There was a negative relationship between the percentage of algae consumed and the $\mathrm{N}$ content in algal tissues, suggesting compensatory feeding by herbivores. Herbivory reduced the biomass accumulation rate of $U$. lactuca when $\mathrm{PO}_{4}{ }^{3-}$ or no nutrients were added, but not when $\mathrm{NO}_{3}{ }^{-}$was added. In the absence of herbivory, the addition of nutrients did not increase $U$. lactuca biomass accumulation rate. These results suggest that nutrients remain high enough for adequate time intervals to be assimilated by macroalgae and support blooms. Large water exchange during tidal changes, however, can diminish the potential negative effects of macroalgal accumulation (oxygen depletion, high ammonium concentrations) on herbivores such that herbivores can have a large impact on macroalgae.
\end{abstract}

KEY WORDS: Top-down vs. bottom-up controls $\cdot$ Coastal eutrophication $\cdot$ Tidal influence $\cdot$ Ulva lactuca $\cdot$ Nutrients $\cdot$ Herbivory

\section{INTRODUCTION}

One of the main assumptions in coastal eutrophication studies is that eutrophication causes a significant shift in benthic communities along with great losses of both species and functional diversity (Smith \& Schindler 2009). Ultimately, these changes are detrimental for the whole ecosystem and its goods and services (McGlathery et al. 2007).

The most common cause of eutrophication is the addition of nutrients that are mainly derived from land (Nixon 1995, Cloern 2001, Valiela 2006). Increases in nutrient loads typically lead to higher primary production, with consequent changes in the composition and abundance of flora and fauna (e.g. Duarte 1995, Borum \& Sand-Jensen 1996). When eutrophication is incipient, the growth of macroalgae may be positive due to short-term sequestration of nutrients (Howarth et al. 1996, Boyer et al. 2002), providing abundant food particles of high nutritional quality for consumers (Hemmi \& Jormalainen 2004). As eutrophication progresses, the accumulation of macroalgae may have negative effects on the system (Smith \& Schindler 2009). Macroalgae consume oxygen at night, driving hypoxic events. During the day, the oxygen produced by photosynthesis can restore the oxygen concentration in the water, but a succession of a few cloudy days may prevent this, resulting in near-bottom water becoming 
anoxic (D'Avanzo \& Kremer 1994). Moreover, bacterial decomposition of macroalgal biomass consumes oxygen (Viaroli et al. 1996), which can cause periods of extended and persistent anoxia. These events of hypoxia and anoxia affect the survival of many organisms such as fishes, shellfishes, and other consumers, including macroalgal grazers (D'Avanzo \& Kremer 1994, Fox et al. 2009). Thus, environments with high nutrient loads are characterized by the dominance of fast-growing seaweeds that leads to hypoxic and anoxic events in sediments and near-bottom waters and, consequently, lower abundance and diversity of organisms.

Under this scenario of high nutrient supply and reduction of consumer (including grazer) abundance, most of these systems become bottom-up controlled and top-down control may be negligible (Carpenter et al. 1985, Menge 1992, Raffaelli et al. 1998). In fact, with the exception of rocky shores (Lubchenco 1978, Lotze \& Worm 2000), most evidence from coastal areas in temperate latitudes suggests that nutrients are responsible for macroalgal blooms (Sfriso et al. 1992, Valiela et al. 1992, Raffaelli et al. 1998, Burkepile \& Hay 2006, Teichberg et al. 2008). In these areas, $\mathrm{N}$ is the most common nutrient limiting growth of producers (Ryther \& Dunstan 1971, Howarth 1988). Phosphorus can also be limiting for macroalgal growth at some times of the year (Peckol et al. 1994), in N-rich environments (Teichberg et al. 2010) or in carbonate-rich tropical environments (Lapointe et al. 1992).

The effect of nutrient supply on coastal ecosystems may be modified or mediated by hydrodynamics. Most eutrophic sites are subject to low water exchange that concentrate nutrients, as well as photosynthetic products (Cloern 2001). Under high tidal exchange, nutrients may be swept quickly out to sea (Howarth et al. 1996), and hypoxia may be prevented. If the residence time within an estuary is short, primary producers might have insufficient time to grow in response to the nutrient supply within that particular estuary (Monbet 1992, Pace et al. 1992). In addition, free-living or ephemeral attached macroalgae with high transportation potential are much more abundant in meso and microtidal estuaries where the residence time is longer and the hydrodynamic forcing is less (Flindt et al. 2004). Thus, hydrodynamics may control algal growth by limiting the time of exposure to nutrients and, concomitantly, the internal nutrient content in thalli that determines growth rate (Pedersen \& Borum 1996). In addition, herbivores may consume different amounts of algae depending on the nutrient content in the algal tissues (Cruz-Rivera \& Hay 2000, Giannotti \& McGlathery 2001). Consequently, both bottom-up and top-down processes could be affected by hydrodynamics.
The Argentine Patagonian coast is currently subjected to increasing $\mathrm{N}$ loading (Teichberg et al. 2010). The human population is growing and the associated wastewater has become one of the primary sources of $\mathrm{N}$, given the lack of agricultural activities and thus low fertilization input. The absence of wastewater treatment plants has led to episodes of eutrophication near human settlements. San Antonio Bay (see Fig. 1) reflects recent changes along the Patagonian coastline due to increased human population size and high nutrient loading. This is a system with high nutrient concentrations $\left(\approx 121 \mu \mathrm{M}\right.$ for DIN and $\approx 5 \mu \mathrm{M}$ for $\mathrm{PO}_{4}{ }^{3-}$, Teichberg et al. 2010) that are similar to those found in the central basin of the Venice lagoon (Solidoro et al. 2010), which is a recognized highly eutrophic site.

San Antonio Bay is subject to a semidiurnal symmetric macrotidal regime (up to $9 \mathrm{~m}$ ) that leads to a large flushing of water twice a day. This considerable water exchange partly relieves the land-derived $\mathrm{N}$ loads delivered to San Antonio Bay. Besides the large exchange of water, there are areas with high macroalgal biomass and diversity near the town of San Antonio Oeste (see Fig. 1; Martinetto et al. 2010). The average growth velocity of Ulva lactuca at this site is 20 to $25 \%$ $\mathrm{d}^{-1}$, which is 2 to 5 -fold higher than those reported in some eutrophic sites around the world (Mondego estuary, Venice lagoon, and Urias estuary; Teichberg et al. 2010). The abundance of consumers is also high in San Antonio Bay (Iribarne et al. 2003, Martinetto et al. 2010), but there are notable differences, with larger populations of consumers in areas closer to human activity where release of nutrients is higher (Martinetto et al. 2010). The abundance of benthic and epibenthic invertebrates and shorebirds is higher in this area. Thus, macroalgal blooms in this system are coupled to a larger abundance of organisms, rather than to a limited survival of consumers. We conjecture that the strength of top-down and bottom-up forces under conditions of high nutrient loads, high growth rates of macroalgae, and high herbivore abundances that are unlimited by oxygen concentrations, should be different from what has been previously shown.

In this paper, we report on the relative importance of bottom-up and top-down controls on macroalgae in San Antonio Bay, a macrotidal system where nutrient supply and consumer abundance are both unusually high. For this purpose, we carried out 2 investigations to evaluate (1) whether land derived nutrients, $\mathrm{pH}$, and $\mathrm{O}_{2}$ concentrations increased during low tide and were diluted during high tide, and whether tidal channels of San Antonio Bay nearer to human activity differ in nutrient concentrations, isotopic signatures and internal nutrient pools of algal thalli from those farther from human settlement, and (2) whether different internal nutrient pools in thalli or external $\mathrm{NO}_{3}{ }^{-}$or $\mathrm{PO}_{4}{ }^{3-}$ supply 
and the presence or absence of grazing resulted in differences in biomass accumulation rates of Ulva lactuca.

\section{MATERIALS AND METHODS}

Study site. Water quality variables were measured in 2 tidal channels of San Antonio Bay: one running nearby and along the town of San Antonio Oeste (hereafter SAO channel; Fig. 1) and another running parallel to the first, but separated from it by a long bar that breaks the second channel's contact with populated areas (hereafter control channel). The bay is $80 \mathrm{~km}^{2}$ in area and is characterized by an extensive intertidal (mainly sand/pebble flats) surrounded by salt marshes (mainly Spartina alterniflora; Isacch et al. 2006). Given the low average rainfall $\left(\sim 250 \mathrm{~mm} \mathrm{yr}^{-1}\right.$; see Isacch et al. 2006), there is almost no freshwater input to the bay via precipitation, making the bay generally hypersaline (Pascual et al. 2001). Septic systems from dwellings along the coast furnish the major source of freshwater to this system via groundwater. This freshwater input is N-rich and affects the SAO channel where high DIN concentrations and canopies of opportunistic fast-growing seaweeds have been reported (Martinetto et al. 2010, Teichberg et al. 2010). Another source of land-derived nutrients is a fish processing factory located on the shore in the innermost part of the SAO channel.

Although we compared nutrient concentrations, algal internal nutrient pools and stable isotopic signatures of $\mathrm{C}$ and $\mathrm{N}$ between samples obtained from the 2

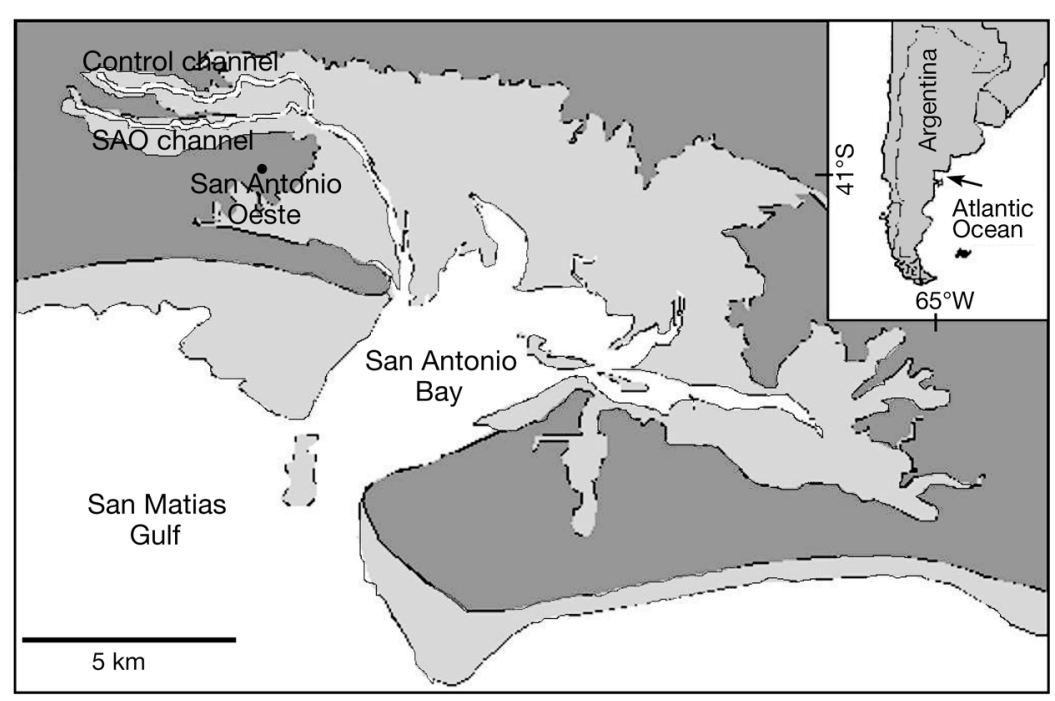

Fig. 1. San Antonio Bay showing flooded area during high tide (light grey) and area under water during low tide (white). The San Antonio Oeste (SAO) channel passes through the town of San Antonio Oeste while the control channel is situated farther away from human activities channels, we did not have site replication, given that truly independent site replicates in nature are virtually impossible to find. However, several similar studies have been published (e.g. Geertz-Hansen et al. 1993, McClelland \& Valiela 1998). This is a limitation imposed by the nature of the system that we cannot solve; hence, we assume limitations of our inference to other systems imposed by the lack of site replication. The manipulative experiments were designed to evaluate the response of Ulva lactuca growing in a system with high nutrient concentrations and high herbivory, so all the experiments were performed in the SAO channel.

Links among water quality, Ulva lactuca $\mathbf{N}$ and $\mathbf{P}$ internal pools, macroalgal cover, and grazer abundance. To determine whether there were differences in water quality between low and high tide and between channels, we measured $\mathrm{NH}_{4}{ }^{+}, \mathrm{NO}_{3}{ }^{-}, \mathrm{PO}_{4}{ }^{3-}$, salinity, $\mathrm{pH}$, and $\mathrm{O}_{2}$ concentrations in the water at both tidal channels. Access to the control channel was possible only during low tide, while the SAO channel was sampled during both low and high tides. Water samples were taken with $60 \mathrm{ml}$ syringes (6 replicates per tide and channel). To cover yearly fluctuations, measurements were done every 2 to 3 mo between March 2006 and March 2008. Nutrients were determined using standard colorimetric methods-phenolhypochlorite method for $\mathrm{NH}_{4}{ }^{+}$(Solorzano 1969), cadmium reduction method for $\mathrm{NO}_{3}^{-}$(Strickland \& Parsons 1972), and Strickland \& Parsons' (1968) method for $\mathrm{PO}_{4}{ }^{+}$. Salinity, $\mathrm{pH}$, and $\mathrm{O}_{2}$ were measured in situ using a multivariable probe (Horiba U-10). Differences in nutrients and chemical variables among high and low tide in the SAO channel and low tide in the control channel (total of 3 locations) over time (total of 9 dates) were evaluated using 2-way ANOVA for each dependent variable. When an interaction between factors was significant, Tukey tests were applied to determine how factors interacted.

To assess whether the differences in nutrients in the ambient water result in different nutrient contents and isotopic signatures in macroalgal thalli, we determined $\mathrm{C}, \mathrm{N}$, and $\mathrm{P}$ internal pools and $\delta^{13} \mathrm{C}$ and $\delta^{15} \mathrm{~N}$ in Ulva lactuca thalli collected in the channels at the sites where nutrient samples were taken. To cover seasonal variation, samples were collected in the 2 channels in August and November 2007 for winter and spring, and in January and April 2008 for summer and fall respectively. We collected 3 composite samples (3 to 5 thalli each) per sampled month and 
channel. The thalli were rinsed with deionized water, dried in an oven at $60^{\circ} \mathrm{C}$, ground to a fine powder, weighed, and loaded into tin capsules. Determination of $\mathrm{C}$ and $\mathrm{N}$ percentages and stable isotope analyses were performed by mass spectrometry in the Stable Isotope Laboratory at The Ecosystems Center, Marine Biological Laboratory (Woods Hole, MA). Phosphorus content was measured in summer and fall samples using colorimetry after extraction of $\mathrm{PO}_{4}{ }^{3-}$ (McGlathery et al. 1994) from thalli. Differences in nutrient contents and ratios as well as in isotopic signatures among seasons and channels were evaluated using 2-way ANOVA for each dependent variable.

To evaluate whether the concentration of nutrients in the ambient water was related to algal cover, we performed regression analyses between percent algal cover and the concentrations of $\mathrm{NH}_{4}{ }^{+}, \mathrm{NO}_{3}{ }^{-}$, and $\mathrm{PO}_{4}{ }^{3-}$ determined at low tide. We also evaluated the relationship between percent algal cover and the differences in $\mathrm{O}_{2}$ concentration between low and high tide and the percent increment in $\left[\mathrm{H}^{+}\right]$at high tide. Proton concentration was calculated as: $\left[\mathrm{H}^{+}\right]=10^{-\mathrm{pH}}$. Algal cover data was obtained from a previous study (Martinetto et al. 2010) in which percent algal cover was determined visually every 2 to 3 mo over a year (total of 5 dates) from ten $1 \mathrm{~m}$-side quadrats placed randomly in the low intertidal area where chemical variables were measured. Significance of regressions was tested using the F-test.

As data on the abundance of herbivorous amphipods and small snails is available from a previous study (Martinetto et al. 2010), we only compared the abundance of chitons and limpets in the present study. Based on data from a food web study carried out in this area (P. Martinetto unpubl. data), we knew that chitons (Chaetopleura isabellei) and keyhole limpets (Fissurella spp.) were the main macroalgal consumers together with amphipods and small snails. To determine herbivore abundance, twenty $25 \mathrm{~cm}$-side quadrats were randomly surveyed, and all the chitons and keyhole limpets inside the squares were counted. Differences in the abundances of grazers between sites were evaluated using $t$-tests.

Relative effects of internal nutrient pools and herbivory on Ulva lactuca growth. To evaluate the relative effects of internal nutrient pools and herbivory on Ulva lactuca growth, we experimented on algae with different $\mathrm{N}$ and $\mathrm{P}$ contents, and with and without herbivory. Thalli were collected from both channels. Three thalli from the same channel were weighedblotted wet wt $=5.2 \pm 1.0(\mathrm{SD}) \mathrm{g} \mathrm{cage}^{-1}$-and placed inside cages $(20 \times 20 \times 15 \mathrm{~cm})$ constructed with transparent Plexiglas $(0.5 \mathrm{~cm}$ thickness) with 2 sides covered by mesh allowing water flow (Teichberg et al. 2008). Two mesh sizes (1 and $10 \mathrm{~mm}$ ) were used to exclude or admit small herbivores. Use of this type of incubation cage in previous studies of algal growth in different coastal areas around the world showed no cage effect (Teichberg et al. 2010).

The experiment consisted of 2 factors: initial internal pool of nutrients (low: control channel; high: SAO channel) and herbivory (with or without herbivores). Eight replicate cages for each treatment combination were set $2 \mathrm{~m}$ apart, hanging in a line within the existing macroalgal canopy in the SAO channel. After $12 \mathrm{~d}$ of field incubation, algae inside the cages were weighed. We measured the biomass accumulated by Ulva lactuca from initial and final weights of algae within each cage. Exponential biomass accumulation rates were determined as: biomass accumulated $\left(\mathrm{g} \mathrm{d}^{-1}\right)=(\ln$ final wet $\mathrm{wt}-\ln$ initial wet $\mathrm{wt}) /$ days of incubation.

During the incubation, the algae may incorporate or release nutrients. Since growth is related to the internal nutrient pool in the thalli, we examined changes in the internal nutrient content. The thalli from each cage were also dried and ground for the determination of $\mathrm{C}$ and $\mathrm{N}$ contents and isotopic signatures as an indicator of the turnover rates of these elements. Phosphorus content was measured as described earlier. Initial C, N, and $\mathrm{P}$ contents as well as stable isotopic signatures of $\mathrm{C}$ and $\mathrm{N}$ were measured in 5 samples consisting of 3 to 5 thalli each, which were collected from both channels. Differences in biomass accumulation rates, nutrient contents, and isotopic signatures among treatments were evaluated using 2-way ANOVA, with initial internal nutrient pool and herbivory as factors.

To evaluate whether consumption by herbivores was related to nutrient content in algal thalli, we performed regression analyses between the percentage of algae consumed in each cage in the treatments with herbivory, and the percentage of $\mathrm{N}, \mathrm{C}$, and $\mathrm{P}$ and the $\delta^{13} \mathrm{C}$ and $\delta^{15} \mathrm{~N}$ in the thalli. The percentage of algae consumed was calculated as: [(estimated final wt without herbivory - final wt with herbivory) $\times 100$ ] / estimated final wt without herbivory. The final weight without herbivory was estimated using the mean biomass accumulation rate in the $1 \mathrm{~mm}$ mesh cages.

Bottom-up vs. top-down effects on net growth of Ulva lactuca. To evaluate the relative impacts of $\mathrm{NO}_{3}{ }^{-}$ and $\mathrm{PO}_{4}{ }^{3-}$ supply and herbivory on the proliferation of $U$. lactuca, a second experiment was conducted using the same type of incubation cage. In each cage, 3 thalli of $U$. lactuca from the SAO channel were incubated under different treatments combining nutrients and herbivory. The experiment had a cross-classified 2 factor design with 3 treatments of nutrient supply $\left(\mathrm{NO}_{3}{ }^{-}\right.$ addition, $\mathrm{PO}_{4}{ }^{3-}$ addition, no nutrient addition), and 2 herbivory treatments (with and without herbivory) (6 treatments, 4 replicate cages for treatments without 
herbivory and 8 for those with herbivory). To deliver $\mathrm{N}$ and $\mathrm{P}$ to macroalgal thalli in the cages, $\mathrm{NO}_{3}{ }^{-}$and $\mathrm{PO}_{4}{ }^{3-}$ solutions were prepared by dissolving $\mathrm{KNO}_{3}$ and $\mathrm{KH}_{2} \mathrm{PO}_{4}$ in a $3 \%$ agar solution, making a $2 \mathrm{M} \mathrm{KNO}_{3}$ or $1 \mathrm{M} \mathrm{KH}_{2} \mathrm{PO}_{4}$ solution. Perforated PVC pipes were filled with the agar and placed at the center of each cage to allow for slow release over the course of the experiment. To manipulate the presence and absence of herbivores, we used different mesh sizes (1 or $10 \mathrm{~mm}$ ) as described above in the first experiment. After $12 \mathrm{~d}$, the incubation chambers were removed and the algae inside the cages were weighed. Differences in the biomass accumulation rates among treatments were evaluated using 2-way ANOVA for unbalanced data (Shaw \& Mitchell-Olds 1993) since the number of replicates differed among treatments.

Although the effectiveness of nutrient delivery of this method has been tested (Teichberg et al. 2008), we evaluated the effectiveness of the nutrient addition by sampling water inside and outside (ambient water) the cages on incubation days $2,6,9$, and 11 . Differences in nutrient concentrations among different mesh sizes and nutrient addition treatments were pooled for the incubation period and evaluated using 2-way ANOVA.
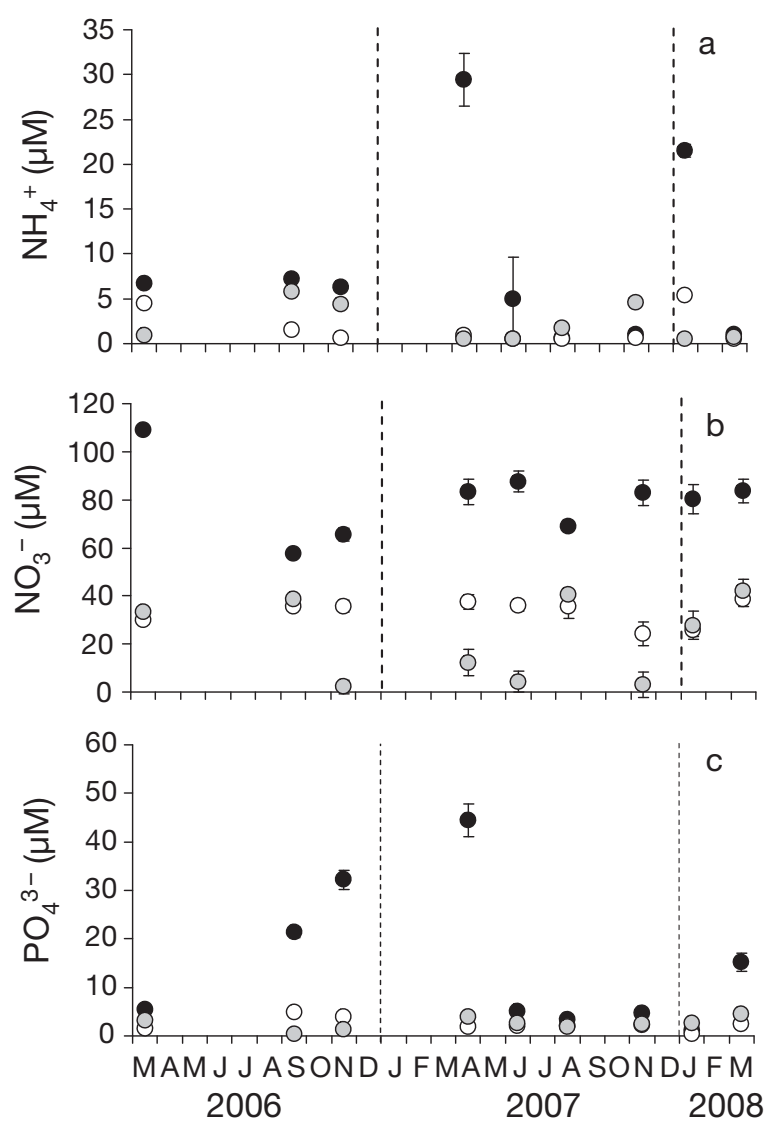

\section{RESULTS}

\section{Links among water quality, Ulva lactuca $\mathbf{N}$ and $\mathbf{P}$ internal pools, macroalgal cover, and grazer abundance}

Concentrations of $\mathrm{NH}_{4}{ }^{+}, \mathrm{NO}_{3}{ }^{-}$, and $\mathrm{PO}_{4}{ }^{3-}$ were generally higher during low tide in the SAO than in the control channel or during high tide in the SAO channel (Fig. 2a-c). However, there were interactions between factors (location and time) in the concentration of nutrients (interactions: $F_{16,96}=4.071, \mathrm{p}<0.001 ; F_{16,96}=$ $3.601, \mathrm{p}<0.001$; and $F_{16,96}=2.569, \mathrm{p}<0.001$ for $\mathrm{PO}_{4}{ }^{3-}$, $\mathrm{NH}_{4}{ }^{+}$, and $\mathrm{NO}_{3}{ }^{-}$, respectively). Tukey tests revealed that there were no differences in the concentrations of $\mathrm{PO}_{4}{ }^{3-}$ in January 2008, $\mathrm{NH}_{4}{ }^{+}$in June 2007 and March 2008, and $\mathrm{NO}_{3}{ }^{-}$in November 2006.

$\mathrm{pH}$ and $\mathrm{O}_{2}$ concentrations were also higher during low tide than during high tide in the SAO channel and higher than those during low tide in the control channel (Fig. 2d,e; factor location: $F_{2,60}=58.309$, p $<0.001$; $F_{2,60}=12.434, \mathrm{p}<0.001$ for $\mathrm{pH}$ and $\mathrm{O}_{2}$ respectively) with no variation over time. Salinity was not different between high and low tide in the SAO channel or
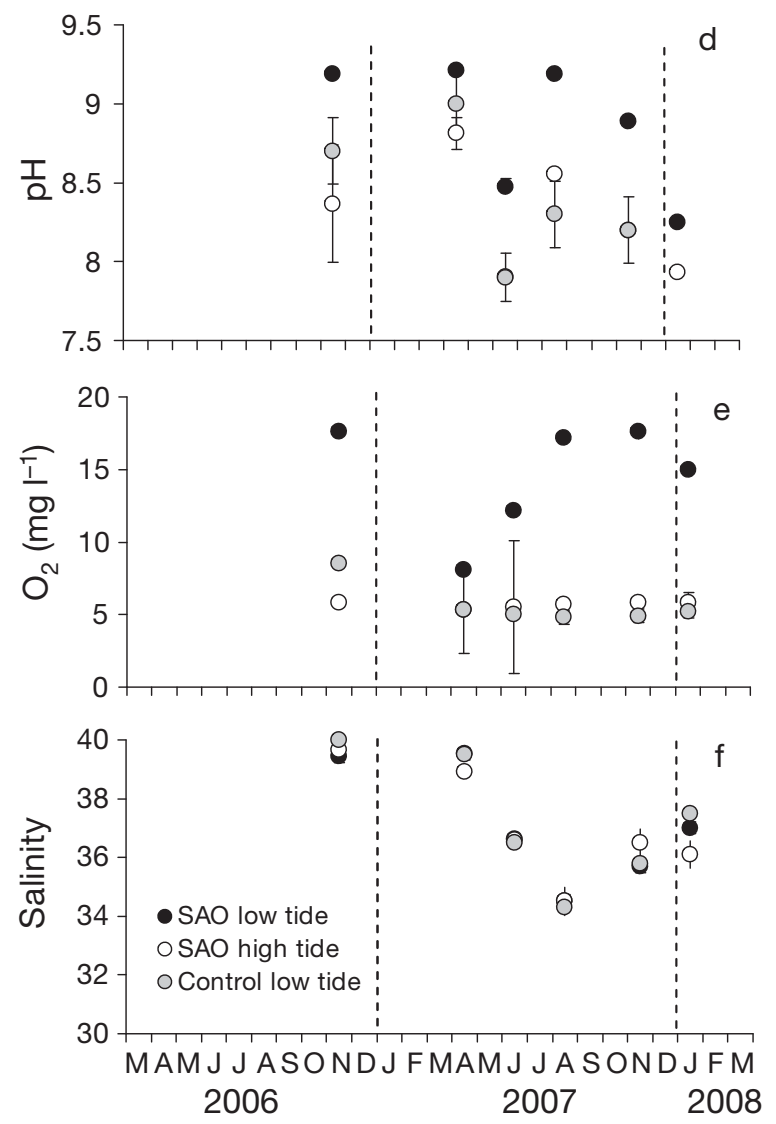

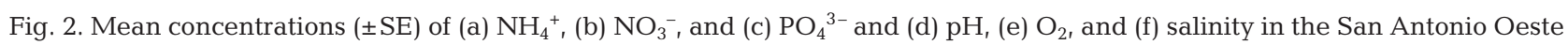
(SAO) channel during high and low tide and in the control channel during low tide 
between channels or over time (Fig. 2f; factor location: $F_{2,60}=34.268, \mathrm{p}=0.790$; factor time: $F_{2,60}=14.385, \mathrm{p}=$ 0.928).

Carbon content was higher in thalli collected from the SAO channel than in those collected from the control channel during spring, summer and fall, while there were no differences between locations in winter (Table 1). The percent $\mathrm{N}$ in thalli of Ulva lactuca showed interaction between factors (Table 1B), with higher percent $\mathrm{N}$ in thalli collected from the SAO than in those from the control channel except for thalli collected in summer which did not show differences between locations (Table 1A). The percent $\mathrm{P}$ was higher in thalli from the SAO than in those from the control channel and it was also higher in fall (Table 1). The $\mathrm{C}: \mathrm{N}$ ratio showed interaction between factors (Table 1B), with higher values in the control than in the SAO channel in winter, spring, and fall and no difference between locations in summer (Table 1A). C:P and $\mathrm{N}: \mathrm{P}$ ratios were higher in the control than in the SAO channel, and they were also higher in summer than in fall (Table 1). $\delta^{15} \mathrm{~N}$ signatures were higher in thalli from the SAO than in those from the control channel (Table 1). $\delta^{13} \mathrm{C}$ signatures showed interaction between factors (Table 1B), with higher signatures in the SAO than in the control channel over the year, except in winter when values were not different between locations (Table 1A).

Macroalgal cover was negatively related to $\mathrm{NH}_{4}{ }^{+}$concentration (Fig. 3a), but not to $\mathrm{NO}_{3}{ }^{-}$or $\mathrm{PO}_{4}{ }^{3-}$ concentration (Fig. 3b,c). It was also positively related to changes in $\mathrm{H}^{+}$and $\mathrm{O}_{2}$ concentrations between tides (Fig. 3d,e).

Similar to the published abundance data on amphipods and small snails (Martinetto et al. 2010), the density of chitons and limpets was higher in the SAO than in the control channel $(t=2.145, \mathrm{p}=0.006)$. Density of chitons in the SAO channel was 22.93 ind. $\mathrm{m}^{-2}$ (SE = 5.082) while that in the control channel was 0.53 ind. $\mathrm{m}^{-2}(\mathrm{SE}=0.363)$. Keyhole limpets were only present in the SAO channel (20.27 ind. $\left.\mathrm{m}^{-2}, \mathrm{SE}=12.223\right)$.

Table 1. Ulva lactuca. (A) Mean $( \pm \mathrm{SE}$ ) percentages of $\mathrm{C}, \mathrm{N}$, and $\mathrm{P}$ content, C:N, C:P, and N:P ratios, and C and N isotopic signatures in thalli from two tidal channels of San Antonio Bay: one near San Antonio Oeste town (SAO) and the other farther away from human activity (control). Percentage of $\mathrm{P}$ was measured only in summer and fall. (B) The respective 2-way ANOVA results for each of these variables, with season and location as main factors

\begin{tabular}{|c|c|c|c|c|c|c|c|c|c|}
\hline \multicolumn{2}{|c|}{ (A) Means \pm SE } & \multirow[b]{2}{*}{ Winter } & \multirow[b]{2}{*}{ Spring } & \multirow[b]{2}{*}{ Summer } & \multirow[b]{2}{*}{ Fall } & \multicolumn{2}{|c|}{ (B) ANOVA results } & \multirow[b]{2}{*}{$F$} & \multirow[b]{2}{*}{$\mathrm{p}$} \\
\hline Variable & Location & & & & & Source & df & & \\
\hline \multirow[t]{4}{*}{$\% \mathrm{C}$} & Control & $34.2 \pm 0.8$ & $33.8 \pm 0.2$ & $34.8 \pm 0.2$ & $30.1 \pm 0.8$ & Season & 3 & 21.5 & $<0.001$ \\
\hline & SAO & $35.0 \pm 0.6$ & $36.0 \pm 0.4$ & $36.2 \pm 0.2$ & $31.8 \pm 2.3$ & Location & 1 & 6.8 & $<0.001$ \\
\hline & & & & & & Interaction & 3 & 0.8 & 0.512 \\
\hline & & & & & & Error & 37 & & \\
\hline \multirow[t]{4}{*}{$\% \mathrm{~N}$} & Control & $2.2 \pm 0.2$ & $2.2 \pm 0.2$ & $3.5 \pm 0.0$ & $2.2 \pm 0.5$ & Season & 3 & 2.3 & $<0.001$ \\
\hline & SAO & $4.5 \pm 0.2$ & $3.5 \pm 0.2$ & $3.5 \pm 0.1$ & $3.7 \pm 0.8$ & Location & 1 & 45.6 & $<0.001$ \\
\hline & & & & & & Interaction & 3 & 6.96 & 0.001 \\
\hline & & & & & & Error & 37 & & \\
\hline \multirow[t]{4}{*}{$\% \mathrm{P}$} & Control & & & $0.01 \pm 0.0$ & $0.02 \pm 0.0$ & Season & 1 & 7.7 & 0.024 \\
\hline & SAO & & & $0.14 \pm 0.0$ & $0.20 \pm 0.0$ & Location & 1 & 101.4 & $<0.001$ \\
\hline & & & & & & Interaction & 1 & 15.8 & 0.051 \\
\hline & & & & & & Error & 8 & & \\
\hline \multirow[t]{4}{*}{$C: N$} & Control & $18.3 \pm 1.5$ & $18.7 \pm 2.2$ & $11.6 \pm 0.1$ & $14.4 \pm 1.7$ & Season & 3 & 4.7 & 0.007 \\
\hline & SAO & $9.2 \pm 0.3$ & $12.4 \pm 0.6$ & $12.3 \pm 0.3$ & $7.7 \pm 0.2$ & Location & 1 & 55.6 & $<0.001$ \\
\hline & & & & & & Interaction & 3 & 9.1 & $<0.001$ \\
\hline & & & & & & Error & 37 & & \\
\hline \multirow[t]{4}{*}{$\mathrm{C}: \mathrm{P}$} & Control & & & $764.4 \pm 30.0$ & $661.8 \pm 19.1$ & Season & 1 & 9.5 & 0.015 \\
\hline & SAO & & & $263.1 \pm 11.2$ & $221.2 \pm 8.3$ & Location & 1 & 404.9 & $<0.001$ \\
\hline & & & & & & Interaction & 1 & 1.7 & 0.231 \\
\hline & & & & & & Error & 8 & & \\
\hline \multirow[t]{4}{*}{$\mathrm{N}: \mathrm{P}$} & Control & & & $77.0 \pm 2.3$ & $48.4 \pm 6.7$ & Season & 1 & 6.3 & 0.036 \\
\hline & SAO & & & $22.8 \pm 0.9$ & $28.9 \pm 1.3$ & Location & 1 & 68.1 & $<0.001$ \\
\hline & & & & & & Interaction & 1 & 15.2 & 0.054 \\
\hline & & & & & & Error & 8 & & \\
\hline \multirow[t]{4}{*}{$\delta^{13} \mathrm{C}$} & Control & $-14.1 \pm 1.3$ & $-16.1 \pm 0.6$ & $-10.9 \pm 0.2$ & $-16.1 \pm 1.2$ & Season & 3 & 19.9 & $<0.001$ \\
\hline & SAO & $-13.3 \pm 0.4$ & $-12.5 \pm 0.3$ & $-9.6 \pm 0.3$ & $-12.0 \pm 0.8$ & Location & 1 & 28.3 & $<0.001$ \\
\hline & & & & & & Interaction & 3 & 3.2 & 0.033 \\
\hline & & & & & & Error & 37 & & \\
\hline \multirow[t]{4}{*}{$\delta^{15} \mathrm{~N}$} & Control & $12.9 \pm 1.0$ & $8.5 \pm 0.3$ & $8.64 \pm 0.13$ & $8.51 \pm 0.70$ & Season & 3 & 7.4 & 0.001 \\
\hline & SAO & $16.5 \pm 0.5$ & $15.5 \pm 0.3$ & $15.5 \pm 0.3$ & $14.9 \pm 1.1$ & Location & 1 & 79.3 & $<0.001$ \\
\hline & & & & & & Interaction & 3 & 1.5 & 0.230 \\
\hline & & & & & & Error & 37 & & \\
\hline
\end{tabular}



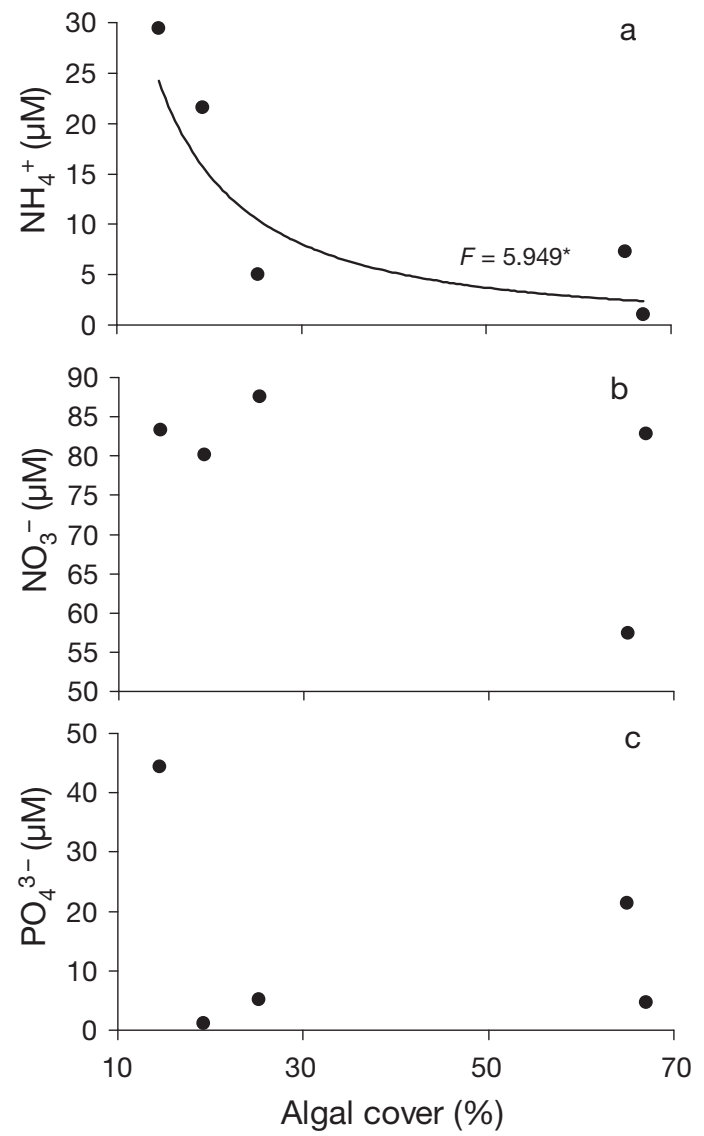

\section{Relative effects of internal nutrient pools and herbivory on Ulva lactuca growth}

Initial $\mathrm{C}, \mathrm{N}$, and $\mathrm{P}$ percentages and $\delta^{13} \mathrm{C}$ and $\delta^{15} \mathrm{~N}$ signatures were higher in $U$. lactuca thalli collected from the SAO than in those from the control channel (Table 1, values registered in fall). After $12 \mathrm{~d}$ of incubation in the SAO channel, there was no difference in the biomass accumulation rate of $U$. lactuca between low and high initial nutrient pool treatments but herbivory reduced the accumulation of $U$. lactuca biomass by $60.83 \%$ (Fig. 4, Table 2). Evidence of herbivory was the presence of holes as well as fragmentation of the margin in thalli incubated in the $10 \mathrm{~mm}$ mesh cages. There were no differences in the final percentages of $\mathrm{C}, \mathrm{N}$, and $\mathrm{P}$ between thalli with different initial nutrient contents but they were higher in thalli subjected to herbivory than in those not exposed to grazers (Fig. 4, Table 2). The same pattern was observed in the $\delta^{15} \mathrm{~N}$ signatures, while the $\delta^{13} \mathrm{C}$ signatures were higher in thalli with high initial internal pool and in those subjected to herbivory. There were no differences between initial and final percentages of $\mathrm{C}, \mathrm{N}$, and $\mathrm{P}$ in thalli with high initial nutrient pools, while thalli with low initial internal pools showed an increase in nutrient contents up to values found in thalli with high ini-

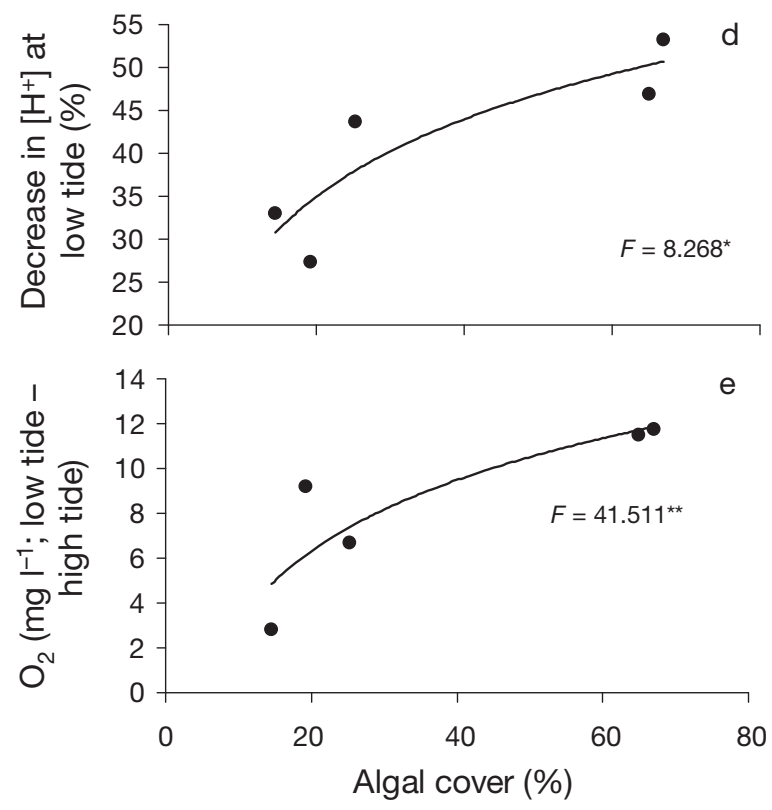

Fig. 3. Ulva lactuca. Percentage of algal cover as a function of (a) $\mathrm{NH}_{4}{ }^{+}$, (b) $\mathrm{NO}_{3}{ }^{-}$, and (c) $\mathrm{PO}_{4}{ }^{3-}$ concentrations, and the differences in (d) $\mathrm{H}^{+}$and (e) $\mathrm{O}_{2}$ concentration between low and high tide. ${ }^{*} p<0.050,{ }^{* *} p<0.005 . r^{2}: 0.645,0.761$, and 0.912 for $\mathrm{NH}_{4}{ }^{+}, \mathrm{pH}$, and $\mathrm{O}_{2}$, respectively

tial internal pools (Fig. 4, Table 2). Thalli with lower initial internal pools had increased $\delta^{13} \mathrm{C}$ and $\delta^{15} \mathrm{~N}$ signatures at the end of the experiment, whereas thalli with higher initial internal pools did not differ in their initial and final signatures (Fig. 4, Table 2). The percentage of algae consumed by grazers was also negatively related to both the $\mathrm{N}$ and $\mathrm{C}$ contents in thalli (Fig. 5a,b), positively related to $\delta^{13} \mathrm{C}$ (Fig. 5d) and not related to the $\mathrm{P}$ content or to $\delta^{15} \mathrm{~N}$ (Fig. $5 \mathrm{c}, \mathrm{e}$ ).

\section{Bottom-up vs. top-down effects on net growth of UIva lactuca}

There were no differences in the concentration of nutrients among cages with different mesh sizes of the control treatment and the ambient water $\left(F_{2,29}=0.307\right.$, $\mathrm{p}=0.820 ; F_{2,29}=1.548, \mathrm{p}=0.215 ; F_{2,29}=0.284, \mathrm{p}=$ 0.836 for $\mathrm{NH}_{4}{ }^{+}, \mathrm{NO}_{3}{ }^{-}$, and $\mathrm{PO}_{4}{ }^{3-}$, respectively). Average concentrations of $\mathrm{NO}_{3}{ }^{-}$were $30.09 \%$ higher inside the cages with $\mathrm{NO}_{3}{ }^{-}$addition $(120.78 \pm 2.53 \mu \mathrm{M}$ vs. $\left.90.69 \pm 1.17 \mu \mathrm{M}, F_{2,29}=4.278, \mathrm{p}=0.042\right)$ and there were no effects of mesh size $\left(F_{2,29}=2.858, p=0.083\right)$. Phosphate showed interaction between mesh size and nutrient addition treatment $\left(F_{2,29}=4.472, \mathrm{p}=0.014\right)$, with $\mathrm{PO}_{4}{ }^{3-}$ concentrations being 40 to $100 \%$ higher 

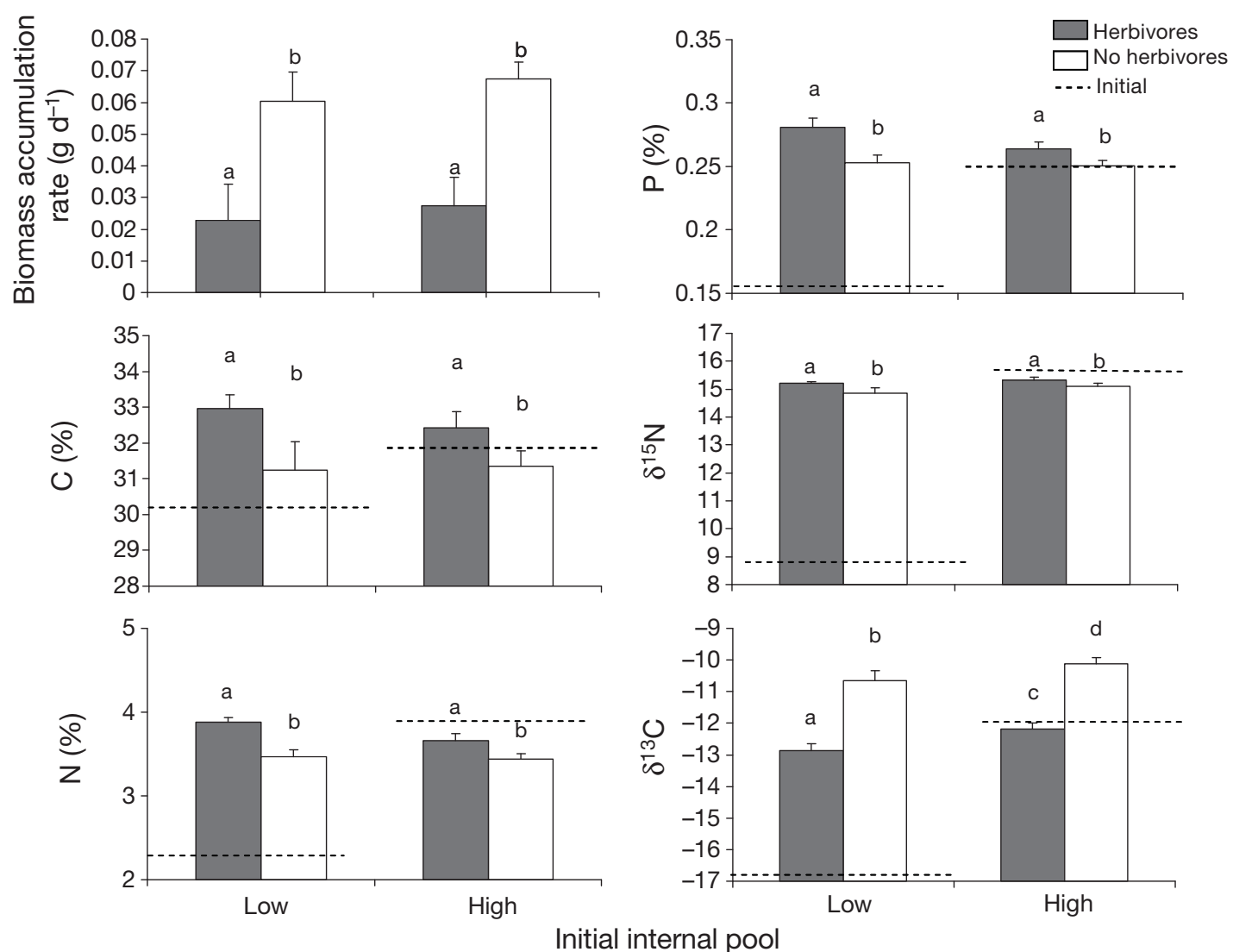

Fig. 4. Ulva lactuca. Biomass accumulation rate, $\mathrm{C}, \mathrm{N}$, and $\mathrm{P}$ percentages and $\delta^{13} \mathrm{C}$ and $\delta^{15} \mathrm{~N}$ isotopic signatures in thalli with different initial nutrient pools and with (grey) or without (white) herbivory after $12 \mathrm{~d}$ of incubation in the San Antonio Oeste (SAO) channel. Different letters indicate significant differences (2-way ANOVA). Dashed horizontal lines indicate initial values before the incubation

inside cages with $\mathrm{PO}_{4}{ }^{3-}$ addition and also higher in cages with $1 \mathrm{~mm}$ mesh $(7.67 \pm 0.98 \mu \mathrm{M}$ vs. $5.35 \pm$ $0.51 \mu \mathrm{M})$.

Herbivory reduced the biomass accumulation rate of Ulva lactuca by 59 and $55 \%$ in the control and $\mathrm{PO}_{4}{ }^{3-}$ addition treatments, respectively (herbivory effect: $F_{1,29}=17.503, \mathrm{p}<0.001$; Fig. 6). In contrast, the biomass accumulation rate of $U$. lactuca was not reduced by herbivory when $\mathrm{NO}_{3}{ }^{-}$was added. In the absence of herbivory, the addition of either $\mathrm{NO}_{3}{ }^{-}$or $\mathrm{PO}_{4}{ }^{3-}$ did not lead to an increase in the U. lactuca biomass accumulation rate (effect of nutrients: $F_{2,29}=$ $0.122, \mathrm{p}=0.886)$.

\section{DISCUSSION}

The results show that nutrients and biological products (e.g. photorespiration products and exudates) in San Antonio Bay are concentrated during low tide and diluted with every high tide. Despite the large flushing of water, nutrients remain in the tidal channels long enough to be assimilated by macroalgae, as was evi- dent in the high internal nutrient pools and $\mathrm{N}$ isotopic signatures found in Ulva lactuca collected in the SAO channel. In addition, U. lactuca showed a high biomass accumulation rate but also supported an intense herbivory pressure that reduced the biomass accumulation by $60 \%$. When nutrients were experimentally added, the accumulated biomass of $U$. lactuca was $45 \%$ higher with $\mathrm{NO}_{3}{ }^{-}$in the presence of herbivores, while there was no response in the accumulated biomass either with $\mathrm{PO}_{4}{ }^{3-}$ addition or with $\mathrm{NO}_{3}{ }^{-}$in the absence of herbivores. Altogether, our results show that under macrotidal conditions, the relationship between bottom-up and top-down regulation may be different from that in other eutrophic systems subject to microtidal regimes where bottom-up forces clearly dominate the structure and dynamics of the ecosystem. In our study systems, water exchange during tidal changes can be large enough to diminish the potential negative effects of macroalgal accumulation (oxygen depletion, ammonium concentration) on herbivores such that herbivores can have a large impact on macroalgae. Below, we discuss the results of the different investigations in this study. 
Table 2. Two-way ANOVA results comparing biomass accumulation rate, $\mathrm{N}, \mathrm{C}$, and $\mathrm{P}$ percentages, and $\delta^{13} \mathrm{C}$ and $\delta^{15} \mathrm{~N}$ signatures of Ulva lactuca thalli from the San Antonio Oeste (SAO) and the control channels (initial internal pool factor) after $12 \mathrm{~d}$ of incubation in the SAO channel with or without small herbivores (herbivory factor)

\begin{tabular}{|c|c|c|c|c|}
\hline & $\mathrm{df}$ & MS & $F$ & $\mathrm{p}$ \\
\hline \multicolumn{5}{|c|}{ Biomass accumulation rate } \\
\hline Initial internal pool & 1 & 0.001 & 0.374 & 0.545 \\
\hline Herbivory & 1 & 0.012 & 16.163 & $<0.001$ \\
\hline Interaction & 1 & 0.001 & 0.015 & 0.904 \\
\hline \multicolumn{5}{|l|}{$\% \mathbf{N}$} \\
\hline Initial internal pool & 1 & 0.125 & 2.569 & 0.120 \\
\hline Herbivory & 1 & 0.816 & 16.712 & $<0.001$ \\
\hline Interaction & 1 & 0.073 & 1.505 & 0.230 \\
\hline \multicolumn{5}{|l|}{$\% \mathrm{C}$} \\
\hline Initial internal pool & 1 & 0.380 & 0.140 & 0.708 \\
\hline Herbivory & 1 & 15.500 & 5.770 & 0.023 \\
\hline Interaction & 1 & 0.810 & 0.300 & 0.586 \\
\hline \multicolumn{5}{|l|}{$\% P$} \\
\hline Initial internal pool & 1 & 0.001 & 2.328 & 0.138 \\
\hline Herbivory & 1 & 0.003 & 10.221 & 0.003 \\
\hline Interaction & 1 & 0.001 & 1.345 & 0.256 \\
\hline \multicolumn{5}{|l|}{$\delta^{15} \mathbf{N}(\%)$} \\
\hline Initial internal pool & 1 & 0.288 & 2.030 & 0.165 \\
\hline Herbivory & 1 & 0.726 & 5.110 & 0.032 \\
\hline Interaction & 1 & 0.036 & 0.260 & 0.617 \\
\hline \multicolumn{5}{|l|}{$\delta^{13} \mathrm{C}(\%)$} \\
\hline Initial internal pool & 1 & 2.912 & 5.287 & 0.029 \\
\hline Herbivory & 1 & 36.822 & 66.839 & $<0.001$ \\
\hline Interaction & 1 & 0.051 & 0.093 & 0.763 \\
\hline
\end{tabular}

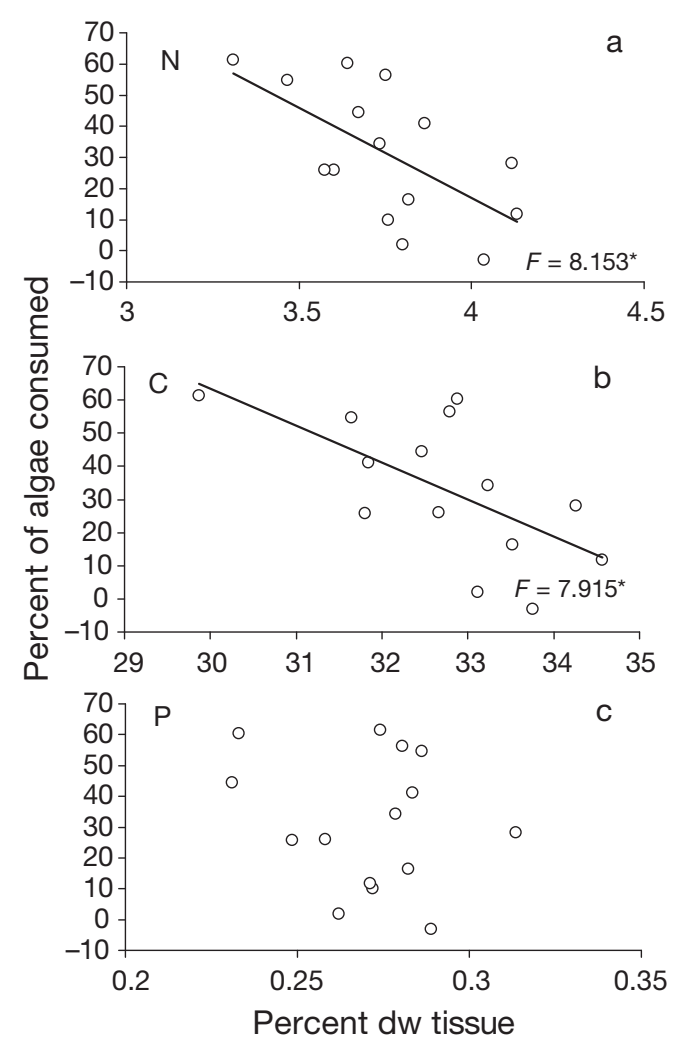

\section{Links among water quality, internal nutrient pools, and macroalgal cover}

Our results show that the concentrations of $\mathrm{NH}_{4}{ }^{+}$, $\mathrm{NO}_{3}{ }^{-}$, and $\mathrm{PO}_{4}{ }^{3-}$ were higher during low tide than during high tide and in the channel nearest to San Antonio Oeste. This suggests a main contribution of nutrients from land that is diluted with sea water during every high tide. The possible land-derived sources of nutrients in this system are a fish processing factory located on the shore in the innermost part of the SAO channel and septic systems from dwellings along the tidal channel. Salinity was not different between high and low tide. This indicates that the amount of freshwater input is relatively small, causing little change in salinity, or that evaporation may be high since the bay is located in a semi-desert ecosystem and a very large intertidal area is exposed during low tide. An estimation of the intertidal area exposed during low tide based on satellite images indicates that sea water during high tide covers an area of almost $120 \mathrm{~km}^{2}$, with $81 \%$ of this area being exposed during low tide (J. P. Isacch pers. comm.).

The differences in values of water quality variables between the channels were also reflected in the internal nutrient pools as well as in the $\mathrm{C}$ and $\mathrm{N}$ stable isotopic signatures of Ulva lactuca thalli. There is evidence that macroalgae can assimilate the $\delta^{15} \mathrm{~N}$ signal of local land-derived $\mathrm{N}$ sources, which are higher due

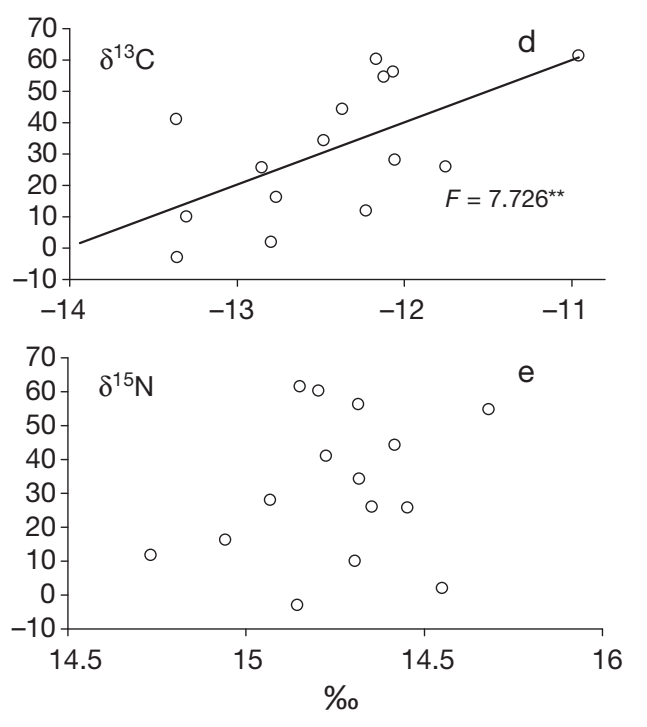

Fig. 5. Ulva lactuca. Percentage of algae consumed as a function of (a) $\mathrm{N}$, (b) C, and (c) P contents, and (d) $\delta^{13} \mathrm{C}$ and (e) $\delta^{15} \mathrm{~N}$ isotopic signatures of thalli after $12 \mathrm{~d}$ of incubation in San Antonio Oeste (SAO) channel. $\left.{ }^{*} \mathrm{p}<0.050,{ }^{* *} \mathrm{p}<0.005\right) . \mathrm{r}^{2}=$ $0.454,0.421$, and 0.560 for $\% \mathrm{~N}, \% \mathrm{C}$, and $\delta^{13} \mathrm{C}$, respectively 


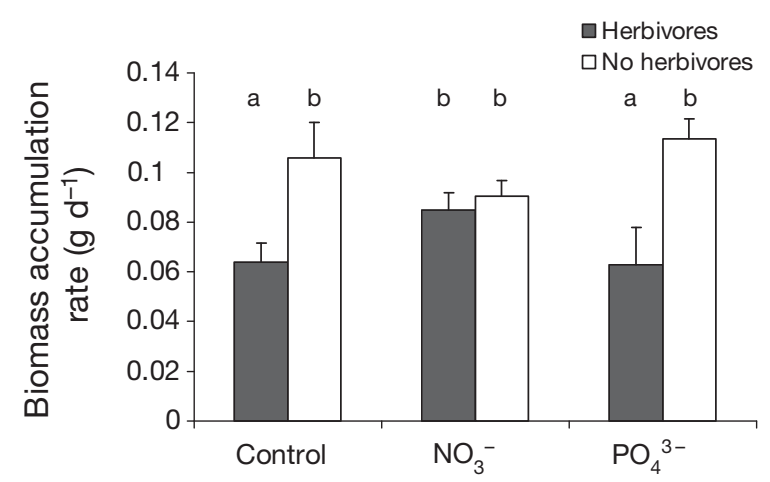

Fig. 6. Ulva lactuca. Biomass accumulation rate of thalli with $\mathrm{NO}_{3}{ }^{-}$and $\mathrm{PO}_{4}{ }^{3-}$ addition and without nutrient addition (control), and with (black) and without (white) herbivory. Different letters indicate significant differences (2-way ANOVA)

to wastewater being the main source of $\mathrm{N}$ (McClelland \& Valiela 1998, Martinetto et al. 2006, Oczkowski et al. 2008). In addition, $\delta^{13} \mathrm{C}$ tends to be higher in eutrophic waters (Gearing et al. 1991, Oczkowski et al. 2008). The percentage of $\mathrm{N}$ and $\mathrm{P}$ in thalli of U. lactuca as well as in other macroalgal species increases with the availability of these elements in the environment (Pedersen \& Borum 1996, Teichberg et al. 2007, 2008). Thus, the higher $\mathrm{N}$ and $\mathrm{P}$ contents and $\mathrm{N}$ and $\mathrm{C}$ stable isotopic signatures found in U. lactuca thalli in the SAO channel may be a result of the higher nutrient availability and the contribution of wastewater in this channel.

Nutrient concentrations reported in this study as well as in a previous study in the area (Martinetto et al. 2010) are high compared to values reported for US estuaries (Holmes 2008) and for other eutrophic coastal areas around the world (Teichberg et al. 2010). Concentrations of $\mathrm{PO}_{4}{ }^{3-}$ in some sampling months were even higher than the highest values reported in these studies. Although $\mathrm{N}$ in wastewater is found mostly as $\mathrm{NH}_{4}{ }^{+}$, DIN in the SAO channel was mostly $\mathrm{NO}_{3}{ }^{-}$. This may be due to intense nitrification activity, in which nitrifying bacteria use energy contained in $\mathrm{NH}_{4}{ }^{+}$, releasing $\mathrm{NO}_{3}{ }^{-}$as an end product (Valiela 1995). Moreover, there was a negative relationship between $\mathrm{NH}_{4}{ }^{+}$ concentrations and macroalgal cover. This relationship could be due to macroalgal preference for $\mathrm{NH}_{4}{ }^{+}$as a $\mathrm{N}$ source (Pedersen \& Borum 1997, Naldi \& Wheeler 2002, Runcie et al. 2003, Cohen \& Fong 2005). Although $\mathrm{NH}_{4}{ }^{+}$is the physiologically preferred form of $\mathrm{N}$ by macroalgae (Thomas \& Harrison 1987), $\mathrm{NO}_{3}{ }^{-}$-rich wastewater delivery to estuaries can also support blooms, and imprint the $\delta^{15} \mathrm{~N}$ signature of $\mathrm{NO}_{3}{ }^{-}$entering the estuary (McGlathery et al. 1997, McClelland \& Valiela 1998, Cole et al. 2006).

$\mathrm{pH}$ and $\mathrm{O}_{2}$ were also higher during low tide. During photosynthesis, many fast-growing green macroalgal species raise the $\mathrm{pH}$ of the water near the surface of thalli as a result of uptake of $\mathrm{HCO}_{3}^{-}$(Beer \& Israel 1990, Larsson \& Axelsson 1999). This involves extracellular dehydration of $\mathrm{HCO}_{3}{ }^{-}$by surface-bound carbonic anhydrase or direct uptake by anion exchange (Larsson et al. 1997). Under conditions of seawater salinity (>30) and $\mathrm{pH}$ (8.1 to 8.2), $\mathrm{CO}_{2}$ concentrations are lower than $\mathrm{HCO}_{3}{ }^{-}$concentrations $\left(0.014\right.$ and $2 \mathrm{~mol} \mathrm{~m}^{-3}$ respectively; Vymazal 1995). During intense photosynthesis, $\mathrm{CO}_{2}$ concentration decreases with increased $\mathrm{pH}$ (Vymazal 1995, Oczkowski et al. 2008) near the algae. Elevated $\mathrm{pH}$ and $\mathrm{O}_{2}$ concentration during low tide, therefore, may be a result of high photosynthetic activity. The positive relationship between changes in $\mathrm{H}^{+}$ and $\mathrm{O}_{2}$ concentration and algal cover supports this idea.

\section{Relative effects of internal nutrient pools and herbivory on Ulva lactuca growth}

In the first experiment, the biomass accumulated by $U$. lactuca was reduced by herbivory by $60 \%$. This reduction is quite high compared to the herbivory rates described in other eutrophic systems. For instance, in Maasholm Bay (Baltic Sea), the relative daily loss rates by herbivory were $29.3 \%$ in Enteromorpha intestinalis and $1.1 \%$ in Pilayella littoralis (Lotze \& Worm 2000). In Waquoit Bay (MA), the grazing effect on U. lactuca in Childs River (a eutrophic estuary) was not significant (Morgan et al. 2003). San Antonio Bay seems to remain in an initial state of eutrophication where there is abundant food of good quality for herbivores. This is evident in the higher density of herbivores found in the SAO channel (Martinetto et al. 2010, present study). Based on the water quality values obtained, it seems probable that the system does not become anoxic (considering $4.6 \mathrm{mg} \mathrm{O}_{2} \mathrm{l}^{-1}$ to be the lower limit for survival of most taxa (Vaquer-Sunyer \& Duarte 2008)) despite the high nutrient availability due to the large water flushing during the tidal cycle. Thus, this could be a case in which eutrophication supports high densities of herbivores by increasing food availability and nutritional content rather than negatively affecting the survival of organisms.

This experiment also showed that there was no difference in the biomass accumulation rate between thalli with different initial internal nutrient pools. The time of incubation was long enough to allow the algae from the control channel to take up excess nutrients and increase internal pools. There are 2 possibilities that may support these results: (1) Nutrients were taken up and used for immediate growth at rates similar to algae from the SAO channel, or (2) the initial percentages of $\mathrm{N}$ in the thalli collected from the control 
and the SAO channels (2.2 and $3.7 \% \mathrm{~N}$ in tissues, respectively) were above the value required for maximum growth (2.2\% N of DW, Pedersen \& Borum 1996). A previous study of Ulva lactuca from a low-nutrient estuary showed an increase in growth rate within $2 \mathrm{wk}$ of nutrient addition (Teichberg et al. 2008), supporting the first scenario. Another study, however, showed a higher growth rate of U. lactuca in thalli with higher $\% \mathrm{~N}$ (Aguiar et al. 2003), concluding that algae growing in nutrient-poor waters grow slower even if they are transplanted into a nutrient-rich environment. Our results indicate that growth rate may depend on internal pool size up to some saturation threshold above which growth rate may remain constant at its maximum.

Percentages of $\mathrm{C}, \mathrm{N}$, and $\mathrm{P}$ were higher in thalli subjected to herbivory than in those not exposed to grazers. One possible explanation could be the excretion of N-rich compounds by grazers. For instance, Thomsen \& McGlathery (2007) found higher growth rates and tissue N contents in Gracilaria vermiculophylla, Ulva curvata, and Agardhiella subulata subjected to herbivory and suggested that grazing could facilitate growth by algal uptake of N-rich compounds excreted by grazing snails.

There is evidence that the $\delta^{13} \mathrm{C}$ in food web components and sediments from eutrophic estuaries are higher than in less productive waters (Gearing et al. 1991, Oczkowski et al. 2008). This pattern has been related to the uptake of $\mathrm{HCO}_{3}^{-}$as a $\mathrm{C}$ source by macroalgae in nutrient-rich sea waters (Oczkowski et al. 2008). The $\delta^{13} \mathrm{C}$ signature in $\mathrm{HCO}_{3}{ }^{-}$is $\sim 10 \%$ higher than that in $\mathrm{CO}_{2}$ (Zhang et al. 1995, Fry 2006). As we mentioned before, many marine macroalgal species can assimilate bicarbonate directly, so it is possible that the observed difference in the $\delta^{13} \mathrm{C}$ signatures is due to differences in the uptake of $\mathrm{HCO}_{3}^{-}$by macroalgae growing under different nutrient supply conditions. The $\delta^{13} \mathrm{C}$ values in thalli from the control channel increased after incubation in the SAO channel, but this increment did not reach the values in thalli from the SAO channel. In contrast, the $\delta^{15} \mathrm{~N}$ after $12 \mathrm{~d}$ was the same for all the thalli independent of their origin. The turnover of $\mathrm{N}$ in Ulva lactuca is relatively rapid at 12 to $15 \mathrm{~d}$ (Aguiar et al. 2003). It is possible that the turnover of $\mathrm{N}$ was faster than that of $\mathrm{C}$, allowing thalli from the control channel to reach the $\delta^{15} \mathrm{~N}$ value of $U$. lactuca from the SAO channel, but not the $\delta^{13} \mathrm{C}$ value.

In addition, the percentage of algae consumed by grazers was negatively related to both $\mathrm{N}$ and $\mathrm{C}$ contents in the thalli and positively related to $\delta^{13} \mathrm{C}$. Consumers select what they eat, and plant nutritional quality (often expressed as tissue $\mathrm{N}$ content) plays a key role in herbivore feeding patterns (Cruz-Rivera \& Hay 2000, Giannotti \& McGlathery 2001, Valentine \& Heck 2001). Most studies show a positive relationship between thalli $\mathrm{N}$ content and preference by herbivores (e.g. Zieman et al. 1984, McGlathery 1995, Giannotti \& McGlathery 2001). In contrast, only a few studies show that herbivores can compensate for low food quality (in terms of $\mathrm{N}$ and $\mathrm{C}$ contents) by eating more (CruzRivera \& Hay 2000, Valentine \& Heck 2001). In San Antonio Bay, the herbivores consumed more algae when the $\mathrm{N}$ and $\mathrm{C}$ contents in the thalli were lower, so it is probable that herbivores compensated for the differences in quality by increasing quantity. Thus, eutrophication may modify grazer-algae interaction by increasing food supply and quality (Korpinen et al. 2007). This modification may change life-history traits and population dynamics of grazers, and potentially affect the regulation of algal communities by herbivory.

\section{Bottom-up vs. top-down effects on Ulva lactuca growth}

In this system, the supply of $\mathrm{N}$ and $\mathrm{P}$ was so high that $U$. lactuca growth did not seem to be limited by these nutrients. This was evident in the lack of response in growth rate in the treatments with nutrient addition excluding grazers. In addition, the experiments show that herbivory plays an important role in controlling $U$. lactuca growth in San Antonio Bay. However, the results also show evidence that the effect of herbivory in controlling $U$. lactuca growth could be broader and directly or indirectly influences the response of algae to an increase in $\mathrm{N}$ supply. Top-down processes have been shown to affect bottom-up processes in coastal marine systems (Porter 1976, Sterner 1986, Bracken \& Stachowicz 2007). For instance, invertebrates may excrete inorganic $\mathrm{N}$ (mainly $\mathrm{NH}_{4}{ }^{+}$), enhancing the diversity of seaweeds (Williamson \& Rees 1994, Bracken \& Nielsen 2004). Herbivores may also reduce $\mathrm{N}$ uptake by selective grazing on specialized tissues (Bracken \& Stachowicz 2007). In terrestrial ecosystems, herbivores may stimulate $\mathrm{N}$ uptake in grasses by removing physiologically less active leaves, inducing specific enzyme activities, and increasing stomatal conductance among others mechanisms (see Anderson et al. 2006). However, our first experiment showed a negative relationship between the percentage of algae consumed and the $\mathrm{N}$ content in thalli, suggesting compensatory feeding. It is possible that when $\mathrm{N}$ was added, herbivores did not consume enough tissue to reduce algal growth, resulting in similar growth rates of $U$. lactuca with and without herbivory. Lapointe \& Tenore (1981), in an experimental outdoor study, reported an increase in the growth rate of Ulva fasciata when $\mathrm{NO}_{3}{ }^{-}$was added under low light condition. Light attenuation inside the incubation cages used in our experiments was tested and no difference was found 
between the inside and outside of cages (Teichberg 2007). Given the similarity between the 1 and $10 \mathrm{~mm}$ mesh size cages, we assume that there is no difference in light attenuation between cages; hence, it seems unlikely that the observed difference in growth rates between cages with different mesh sizes when $\mathrm{NO}_{3}{ }^{-}$ was added was a cage artifact due to light attenuation. To our knowledge, this is the first evidence showing that the combined presence of herbivores and increase in $\mathrm{N}$ supply may stimulate the accumulation of green macroalgal biomass in a system functioning with unusually high nutrient availability and herbivory. Under these conditions, top-down and bottom-up forces interact in the regulation of macroalgal proliferation. Although the ultimate mechanism operating is unknown, the high herbivory pressure and the response to $\mathrm{NO}_{3}{ }^{-}$addition only when herbivores were present provide evidence that both regulatory forces act conjointly.

Acknowledgements. This study was partially funded by (1) an MBL Summer Research Fellowship to P.M., (2) GEF Patagonia, ANPCyT (Argentina) and CONICET (Argentina) funding to O.I., (3) an ECOHAB grant \# NA16OP2728 to I.V., and (4) an NSF Fellowship \# 0534664 awarded to M.T. We thank M. Addino, F. Alvarez, C. Bazterrica, P. Daleo, M. Escapa, and M. Valiñas for field assistance. J. P. Isacch provided some information and helped with map editing. M. Pascual, E. Zampatti, and J. C. Entraigas from the Laboratorio de Producción de Juveniles de Moluscos Bivalvos, Inst. de Biología Marina y Pesquera Alte. Storni provided invaluable logistic support at San Antonio Oeste. M. Otter from the MBL Stable Isotope Laboratory helped with sample analysis and J. Alberti, P. Daleo, S. Fox, and Y. Olsen provided valuable insights on the manuscript.

\section{LITERATURE CITED}

Aguiar AB, Morgan JA, Teichberg M, Fox S, Valiela I (2003) Transplantation and isotopic evidence of the relative effects of ambient and internal nutrient supply on the growth of Ulva lactuca. Biol Bull 205:250-251

> Anderson TM, Dong Y, McNaughton SJ (2006) Nutrient acquisition and physiological responses of dominant Serengeti grasses to variation in soil texture and grazing. J Ecol 94:1164-1175

Beer S, Israel A (1990) Photosynthesis of Ulva fasciata. IV. pH, carbonic anhydrase and inorganic carbon conversions in the unstirred layer. Plant Cell Environ 13:555-560

Borum J, Sand-Jensen K (1996) Is total primary production in shallow coastal marine waters stimulated by nitrogen loading? Oikos 76:406-410

Boyer EW, Goodale CL, Jaworski NA, Howarth RW (2002) Anthropogenic nitrogen sources and relationships to riverine nitrogen export in the northeastern USA. Biogeochemistry 57-58:137-169

Bracken MES, Nielsen KJ (2004) Diversity of intertidal macroalgae increases with nutrient loading by invertebrates. Ecology 85:2828-2836

Bracken MES, Stachowicz JJ (2007) Top-down modification of bottom-up processes: selective grazing reduces macro- algal nitrogen uptake. Mar Ecol Prog Ser 330:75-82

Burkepile DE, Hay ME (2006) Herbivore vs. nutrient control of marine primary producers: context-dependent effects. Ecology 87:3128-3139

Carpenter SR, Kitchell JF, Hodgson JR (1985) Cascading trophic interactions and lake productivity. BioScience 35: 634-639

Cloern JE (2001) Our evolving conceptual model of the coastal eutrophication problem. Mar Ecol Prog Ser 210: 223-253

> Cohen RA, Fong P (2005) Experimental evidence supports the use of $\delta^{15} \mathrm{~N}$ content of the opportunistic green macroalgae Enteromorpha intestinalis (Chlorophyta) to determine $\mathrm{N}$ sources to estuaries. J Phycol 41:287-293

Cole ML, Kroeger KD, McClelland JW, Valiela I (2006) Effects of watershed land use on nitrogen concentration and $\delta^{15}$ nitrogen in groundwater. Biogeochemistry 77:199-215

Cruz-Rivera E, Hay M (2000) Can quantity replace quality? Food choice, compensatory feeding, and fitness of marine mesograzers. Ecology 81:201-219

> D'Avanzo C, Kremer JN (1994) Diel oxygen dynamics and anoxic events in a eutrophic estuary of Waquoit Bay, Massachusetts. Estuaries 17:131-139

Duarte CM (1995) Submerged aquatic vegetation in relation to different nutrient regimes. Ophelia 45:87-112

Flindt MR, Neto J, Amos CL, Pardal MA, Bergamasco A, Pedersen CB, Andersen FØ (2004) Plant bound nutrient transport. Mass transport in estuaries and lagoons. In: Nielsen SL, Banta GT, Pedersen MF (eds.) Estuarine nutrient cycling: the influence of primary producers. Kluwer Academic Publishers, Dordrecht, p 93-128

> Fox SE, Teichberg M, Olsen YS, Heffner LE, Valiela I (2009) Restructuring of benthic communities in eutrophic estuaries: Lower abundance of prey leads to trophic shifts from omnivory to grazing. Mar Ecol Prog Ser 380:43-57

Fry B (2006) Stable isotope ecology. Springer-Verlag, New York, NY

> Gearing PJ, Gearing JN, Maughan JT, Ovlatt CA (1991) Isotopic distribution of carbon sewage sludge and eutrophication in the sediments and food web of estuarine ecosystems. Environ Sci Technol 25:295-301

Geertz-Hansen O, Sand-Jensen K, Hansen DF, Christiansen A (1993) Growth and grazing control of abundance of the marine macroalga, Ulva lactuca L. in a eutrophic Danish estuary. Aquat Bot 46:101-109

Giannotti AL, McGlathery KJ (2001) Consumption of Ulva lactuca (Chlorophyta) by the omnivorous mud snail Illyanassa obsoleta (Say). J Phycol 37:209-215

Hemmi A, Jormalainen J (2004) Genetic and environmental variation in performance of a marine isopod: effects of eutrophication. Oecologia 140:302-311

Holmes GT (2008) Nutrient supply, water residence time, temperature, and grazing as controls of size-fractionated phytoplankton biomass in shallow temperate estuarine ecosystems. PhD dissertation, Boston University, MA

Howarth RW (1988) Nutrient limitation of net primary production in marine ecosystems. Annu Rev Ecol Syst 19:89-110

Howarth RW, Billen G, Swaney D, Townsend A and others (1996) Regional nitrogen budget and riverine $\mathrm{N}$ and $\mathrm{P}$ fluxes for the drainages to the Atlantic Ocean: natural and human influences. Biogeochemistry 35: 75-139

- Iribarne O, Martinetto P, Schwindt E, Botto F, Bortolus A, Garcia Borboroglu P (2003) Evidence of habitat displacement between two common soft-bottom SW Atlantic intertidal crabs. J Exp Mar Biol Ecol 296:167-182

Isacch JP, Costa CS, Rodríguez-Gallego L, Conde D, Escapa M, Gagliardini DA, Iribarne O (2006) Distribution of salt- 
marsh plant communities associated with environmental factors along a latitudinal gradient on the SW Atlantic coast. J Biogeogr 33:888-900

Korpinen S, Honkanen T, Vesakoski O, Hemmi A, Koivikko R, Loponen J, Jormalainen V (2007) Macroalgal communities face the challenge of changing biotic interactions: review with focus on the Baltic Sea. Ambio 36:203-211

Lapointe BE, Tenore KR (1981) Experimental outdoor studies with Ulva fasciata Delile. I. Interaction of light and nitrogen on nutrient uptake, growth, and biochemical composition. J Exp Mar Biol Ecol 53:135-152

Lapointe BE, Littler MM, Littler DS (1992) Nutrient availability to marine macroalgae in siliciclastics versus carbonaterich coastal waters. Estuaries 15:75-82

Larsson C, Axelsson L (1999) Bicarbonate uptake and utilization in marine macroalgae. Eur J Phycol 34:79-86

Larsson C, Axelsson L, Ryberg H, Beer S (1997) Photosynthetic carbon utilization by Enteromorpha intestinalis (Chlorophyta) from a Swedish rockpool. Eur J Phycol 32: 49-54

> Lotze HK, Worm B (2000) Variable and complementary effects of herbivores on different life stages of bloomforming macroalgae. Mar Ecol Prog Ser 200:167-175

Lubchenco J (1978) Plant species diversity in a marine intertidal community: importance of herbivore food preference and algal competitive abilities. Am Nat 112:23-39

Martinetto P, Teichberg M, Valiela I (2006) Coupling of estuarine benthic and pelagic food webs to land-derived nitrogen sources in Waquoit Bay, Massachusetts, USA. Mar Ecol Prog Ser 307:37-48

Martinetto P, Daleo P, Escapa M, Alberti J and others (2010) High abundance and diversity of consumers associated with eutrophic areas in a semi-desert macrotidal coastal ecosystem in Patagonia, Argentina. Estuar Coast Shelf Sci 88:357-364

McClelland JM, Valiela I (1998) Linking nitrogen in estuarine producers to land-derived sources. Limnol Oceanogr 43: 577-585

> McGlathery KJ (1995) Nutrient and grazing influences on a subtropical seagrass community. Mar Ecol Prog Ser 122: 239-252

McGlathery KJ, Marino R, Howarth RW (1994) Variable rates of phosphate uptake by shallow marine carbonate sediments: mechanisms and ecological significance. Biogeochemistry 25:127-146

- McGlathery KJ, Krause-Jensen D, Rysgaard S, Christensen PB (1997) Patterns of ammonium uptake within dense mats of the filamentous algae Chaetomorpha linum. Aquat Bot 59:99-115

> McGlathery KJ, Sundbäck K, Anderson IC (2007) Eutrophication in shallow coastal bays and lagoons: the role of plants in the coastal filter. Mar Ecol Prog Ser 348:1-18

Menge BA (1992) Community regulation: Under what conditions are bottom-up factors important on rocky shores? Ecology 73:755-765

Monbet Y (1992) Control of phytoplankton biomass in estuaries: a comparative analysis of macrotidal and microtidal estuaries. Estuaries 15:563-571

Morgan JA, Aguiar AB, Fox S, Teichberg M, Valiela I (2003) Relative influence of grazing and nutrient supply on growth of the green macroalga Ulva lactuca in estuaries of Waquoit Bay, Massachussetts. Biol Bull 205:252-253

Naldi M, Wheeler PA (2002) ${ }^{15} \mathrm{~N}$ measurements of ammonium and nitrate uptake by Ulva fenestrata (Chlorophyta) and Gracilaria pacifica (Rhodophyta): comparison of net nutrient disappearance, release of ammonium and nitrate, and ${ }^{15} \mathrm{~N}$ accumulation in algal tissue. J Phycol 38:135-144
Nixon SW (1995) Coastal marine eutrophication: a definition, social causes and future concerns. Ophelia 41:199-219

> Oczkowski O, Nixon S, Henry K, DiMilla P and others (2008) Distribution and trophic importance of anthropogenic nitrogen in Narragansett Bay: an assessment using stable isotopes. Estuar Coasts 31:53-69

> Pace ML, Findlay SEG, Lints D (1992) Zooplankton in advective environments: the Hudson River community and a comparative analysis. Can J Fish Aquat Sci 49:1060-1069

Pascual MS, Zampatti EA, Iribarne O (2001) Population structure and demography of the Puelche oyster (Ostrea puelchana, D'Orbigny) grounds in northern Patagonia, Argentina. J Shellfish Res 20:1003-1010

- Peckol P, Demeoanderson B, Rivers J, Valiela I, Maldonado M, Yates J (1994) Growth, nutrient uptake capacities and tissue constituents of the macroalgae Cladophora vagabunda and Gracilaria tikvahiae related to sitespecific nitrogen loading rates. Mar Biol 121:175-185

Pedersen MF, Borum J (1996) Nutrient control of algal growth in estuarine waters. Nutrient limitation and the importance of nitrogen requirements and nitrogen storage among phytoplankton and species of macroalgae. Mar Ecol Prog Ser 142:261-272

Pedersen MF, Borum J (1997) Nutrient control of estuarine macroalgae: growth strategy and the balance between nitrogen requirements and uptake. Mar Ecol Prog Ser 161: 155-163

Porter KG (1976) Enhancement of algal growth and productivity by grazing zooplankton. Science 192:1332-1334

Raffaelli DG, Raven JA, Poole LJ (1998) Ecological impact of green macroalgal blooms. Oceanogr Mar Biol Annu Rev 36:97-125

Runcie JW, Ritchie RJ, Larkum AW (2003) Uptake kinetics and assimilation of inorganic nitrogen by Catenella nipae and Ulva lactuca. Aquat Bot 76:155-174

Ryther JH, Dunstan WM (1971) Nitrogen, phosphorus and eutrophication in the coastal marine environment. Science 171:1008-1013

Sfriso A, Pavoni B, Marcomini A, Orio AA (1992) Macroalgae, nutrient cycles, and pollutants in the Lagoon of Venice. Estuaries 15:517-528

Shaw RG, Mitchell-Olds T (1993) ANOVA for unbalanced data: an overview. Ecology 74:1638-1645

Smith VH, Schindler DW (2009) Eutrophication science: where do we go from here? Trends Ecol Evol 24:201-207

Solidoro C, Bandelj V, Bernardi FA, Camatti E and others (2010) Response of the Venice lagoon ecosystem to natural and anthropogenic pressures over the last 50 years. In: Kennish MJ, Pearl HW (eds.) Coastal lagoons: critical habitats of environmental change. CRC Press, Boca Raton, FL, p 483-511

> Solorzano L (1969) Determination of ammonia in natural waters by the phenolhypochlorite method. Limnol Oceanogr 14:799-801

> Sterner RW (1986) Herbivores' direct and indirect effects on algal populations. Science 231:605-607

Strickland JDH, Parsons TR (1968) A manual for sea water analysis. Bull Fish Res Board Can 167

Strickland JDH, Parsons TR (1972) A practical handbook of seawater analysis, 2nd edn. J Fish Res Board Canada 167

Teichberg M (2007) Macroalgal growth: local and global comparisons of nutrient limitation and assimilation. $\mathrm{PhD}$ dissertation, Boston University, MA

> Teichberg M, Heffner LR, Fox S, Valiela I (2007) Nitrate reductase and glutamine synthetase activity, internal $\mathrm{N}$ pools, and growth of Ulva lactuca: responses to long and short-term N supply. Mar Biol 151:1249-1259 
Teichberg M, Fox S, Aguila C, Osen Y, Valiela I (2008) Macroalgal response to experimental nutrient enrichment in shallow coastal waters: growth, internal nutrient pools, and isotopic signature. Mar Ecol Prog Ser 368:117-126

Teichberg M, Fox SE, Olsen YS, Valiela I and others (2010) Eutrophication and macroalgal blooms in temperate and tropical coastal waters: nutrient enrichment experiments with Ulva spp. Glob Change Biol 16:2624-2637

Thomas TE, Harrison PJ (1987) Rapid ammonium uptake and nitrogen interactions in five intertidal seaweeds grown under field conditions. J Exp Mar Biol Ecol 107:1-8

Thomsen MS, McGlathery KJ (2007) Stress tolerance of the invasive macroalgae Codium fragile and Gracilaria vermiculophylla in a soft-bottom turbid lagoon. Biol Invasions 9:499-513

Valentine JF, Heck KL Jr (2001) The role of leaf nitrogen content in determining turtlegrass (Thalassia testudinum) grazing by a generalized herbivore in the northeastern Gulf of Mexico. J Exp Mar Biol Ecol 258:65-86

Valiela I (1995) Marine ecological processes. Springer-Verlag, New York, NY

Valiela I (2006) Global coastal change. Blackwell Publishing,

Editorial responsibility: Laura Airoldi,

Ravenna, Italy
Malden, MA

Valiela I, Foreman K, LaMontagne M, Hersh D and others (1992) Couplings of watersheds and coastal waters: sources and consequences of nutrient enrichment in Waquoit Bay, Massachusetts. Estuaries 15:443-457

Vaquer-Sunyer R, Duarte CM (2008) Thresholds of hypoxia for marine biodiversity. Proc Natl Acad Sci USA 105: 15452-15457

> Viaroli P, Bartoli M, Bondavalli C, Christian RR, Giordani G, Naldi M (1996) Macrophyte communities and their impact on benthic fluxes of oxygen, sulphide and nutrients in shallow eutrophic environments. Hydrobiologia 329:105-119

Vymazal J (1995) Algae and elemental cycling in wetlands. Lewis Publishers, Boca Raton, FL

Williamson JE, Rees TAV (1994) Nutritional interaction in an algae-barnacle association. Oecologia 99:16-20

Zhang J, Quay PD, Wilbur DO (1995) Carbon isotope fractionation during gas-water exchange and dissolution of $\mathrm{CO}_{2}$. Geochim Cosmochim Acta 59:107-114

Zieman JC, Iverson RL, Ogden JC (1984) Herbivory effects on Thalassia testudinum leaf growth and nitrogen content. Mar Ecol Prog Ser 15:151-158

Submitted: November 17, 2010; Accepted: April 18, 2011 Proofs received from author(s): June 16, 2011 